\title{
Social Sustainable Assessment Tool Development Approach
}

Correspondent Author: Jubril Olakitan Atanda

Department of Architecture, Cyprus International University, Haspolat, Nicosia, Cyprus.

Email: jatanda@ciu.edu.tr

Second Author: Ayşe Öztürk

Department of Architecture, Cyprus International University, Haspolat, Nicosia, Cyprus.

\begin{abstract}
The social criteria of sustainable development have remained underexplored. Moreover, a large number of green building assessment tool and social sustainability documentations have been developed which, has had a direct impact on social criteria issues, but there seems to be a substantial gap in the study of social criteria in green building assessment tools. In examining the problem facing social sustainability, taking into consideration social sustainability in sustainable development reviews and green building assessment tool towards social aspects.

This paper through analysis identified a centripetal conceptual framework composed of seven key components equity, education, participation \& control, social cohesion, health \& safety, accessibility \& satisfaction, and cultural values. The interpretation of the social sustainability in green building assessment tool would impact building practitioners towards implementing social criteria in GBAT. The aim was to identify social categories as well as consider a starting point for the development of an effective social criteria assessment tool for green building.
\end{abstract}

Keywords: Social criteria; Building assessment tools; Sustainable development; social sustainability. 


\section{Introduction}

Green building assessment tool is no longer a new trend in sustainable development. However, this has stimulated a lot of debates and attracted researchers from various aspects. Two basic sets of tools have been derived: the criteria based tools and the life cycle assessment tools. Moreover, enormous researchers have been geared toward the criteria based assessment tool where, CASBEE, BREEAM, Green Star, LEED and many more others have been developed in order to curb the environmental degradation.

Scientific works have demonstrated that sustainable development involves three aspects the environmental criteria, economic criteria, and social criteria. Despite a plentitude of professional perspective and researchers, a stereotypical solution has been conceived. Sadly the environmental criteria have become a flag bearer of most building assessment tool neglecting the social criteria.

Building assessment tools have been developed with a specific end goal to aid the application of sustainable development in the building and construction sector. However, the ideology behind the social criteria remains unclear (Empacher and Wehling, 1999; Kopfmliller et al., 2001; Griebler and Littig, 2004; Dempsey et al., 2011; Casusal Vifell \& Sineyard, 2012). In other words, understanding the social criteria is not well elucidated. Thin (2002), describes it as the most conceptual intangible criteria in sustainable development. This means building practitioners would have to take into considerations a wide range of probabilities to determine this aspect. Littig \& Griessler (2005) was of opinion that the social criteria are more often placed in the aspect of power rather than policy lucidity. This is probably because it's still a new trend for expertise in the architecture, engineering, and construction (AEC) sector. Additionally, an absence of a convincing efficient structure for measuring human results and connecting them to the design elements, make the social perspective complex (Lützkendorf and Lorenz, 2005).

However, despite the global attention drawn to green building assessment tool as a phenomenon, it still lacks a tentative detailed analysis for the social aspect of sustainable development. Moreover, it's important to know the social dimension has not been well documented or emphasized due to the fact that there is no consensus on what social truly means (Lehtonen, 2004). Cuthill, (2009) and Vavik \& Keitsch (2010) also contributed by stating that the social criteria have not received an equal fair of treatment as other two criteria of sustainable development. There is difference about the characterization of the core social indicators of sustainable development (Omann and Spangenberg, 2002). As a result of this, Griebler and Littig (2004) analyzed selected international and national social sustainability concepts, and they came to a conclusion that their selected indicators were not based on theoretical reading other than practical indulgence of a logical and rational agenda politically. This interpretation relates the idea that a clear hypothetical notion for social sustainability is vividly void. Also, this can be due to the fact that people allocate diverse priorities to environmental and social aspects. These occurrences have initiated the urgent need for an effective approach/framework to develop a clearer understanding towards social criteria in building assessment tool.

Despite a plethora of assessment tool in operation, the seamless flow of knowledge and information regarding the social criteria in green building assessment tool is still impeded by a number of factors. Boulding (1985) claims that less accomplishment in the social and biological sciences has been witnessed. The inadequacy of thought towards institutional and financial parts of sustainability is to a great extent attributed to the building driven approach of assessment tools. With tools like BREEAM, LEED, and CASBEE working on a method that totally cogitates the physical and material assets of built environment only (Komeily \& Srinivasam, 2015). An essential test for them is their powerlessness to broadly represent a nitty- 
gritty essential methodology for the distinctive social settings. Moreover, to attain certification from green building assessment tools such as LEED and the rest have become an exclusively customer needs oriented, where designers embark on pursuing credits (Komeily \& Srinivasam, 2015). Existing studies revealed that developers of projects developed by green building assessment tools indulgence criteria with higher point weighting (Sharifi \& Murayama, 2013). Therefore, it is possible that these tools are utilized to guarantee the attractiveness of a group instead of its sustainability. A majority of the assessment tool is expert driven and do not sufficiently involve a comprehensive assessment of stakeholders (Sharifi \& Murayama, 2013; Komeily \& Srinivasam, 2015).

While there is clearly an urgent need for a clear description of social criteria in green building assessment tool. Some of these tools have experienced success in many forms, however, not many of them support an effective outline of social criteria. However, there have been tremendous factors highlighted from literature's that influence the social criteria in green building assessment tool such as, education, equity, participation, health, security, community cohesion and many others to name a few. Therefore, this suggests a need to critically analysis existing green building assessment tool towards their true reaction towards social criteria and social sustainability literature. Thusly drawing from both existing data, the research aimed to identify a generic set of social categories/indicators in existing green building assessment tool and social sustainability literature, in order to highlight the need for implementing these categories/indicators into core context of sustainable development with connection to its logical and provincial focuses to aid building professionals.

\section{Green Building Assessment Tools}

Green building assessment tool evaluates, promote and improve sustainable development in the building industry, and they provide a system that guides and gives a comprehensive understanding of sustainability through data investigation, evaluations, and differentiation (Nguyen \& Altan, 2011). The goal also is to compel a structure that assesses building environmental enactment and incorporating sustainable development into building and construction processes, and they are used as a configuration device by establishing viable design needs and objectives, creating proper design configuration procedures, and deciding measures of performances to control sustainable design and choice making process. Additionally, they give a quantitative performance pointer to design options and a rating for the entire building performance (Cole, 2005).

Building environment seems to comprise of two types of assessment tools: life cycle assessment tools and criteria based tools. A major focus of this research would be on the criteria based tool such as BREEAM, CASBEE LEED, Green Star, GB Tool, GSAS, and SBAT.

\section{BREEAM}

Building Research Establishment Environment Assessment Method (BREEAM) the first assessment tool was developed in 1990, with the most recent updated version produced in 2016 (BREEAM, 2016). Building specification assessment in the design, construction and use phases are the primary focus of BREEAM (BREEAM, 2016).

BREEAM is comprised of four assessment tools, which are utilized in different phases of the building lifespan. Design and Procurement (D\&P) - a design stage process used majorly on building renovation and project extension. Post-Construction Review (PCR) - a verification process when construction is complete. Fit Out assessment - a process used in the renovation 
of existing building and the Management and Operation (M\&O) - evaluation process to assess the building performance during operation. (Saunders, 2008).

BREEAM has nine categories management, energy, ecology, transport, water, material, health \&wellbeing, waste, land use, pollution, and innovation and points given are calculated, which helps defines the environmental impact of the building. Each credit awarded in each category is multiplied the environmental weight point allocated for that category, then the categories score are summed up in an overall scale and are identified as, unclassified, pass, good, very good, excellent, and outstanding. Rating ranging from 1-5 star is provided: 1 star - pass: $30 \%$; 2 stars: - good: 45\%; 3 stars: - 55\%; 4 stars: excellent: 70\%; 5 stars - outstanding: $85 \%$ (BREEAM, 2016).

\section{LEED}

Leadership in Energy and Environmental Design (LEED) a performance-based tool developed and channeled by the U.S. Green Building Council (USGBC) in 1998. Over more than 72,000 LEED certified projects across the world have been accomplished, which makes it a standout amongst the most generally utilized assessment tools (LEED, 2016). LEED Version 4 (LEED, 2013) the newest version was officially launched in 2014, with systems like building design \& construction, building operations \& maintenance, interior design \& construction, neighborhood development and homes introduced. This version of LEED evaluation system focuses on seven main aspects; the sustainable site, indoor environmental quality energy and atmosphere, water efficiency, materials \& resources, innovation in design and regional priority. Building rankings are classified into four levels: certified (40-49), silver (50-59), gold (60-79), and platinum (80above) (LEED, 2013). Without a hesitation, the best concern in regards to the LEED demonstrate is the evident overemphasis on environmental advantage without an equivalent worry for the resilience of the products utilized to accomplish this ecological advantage.

\section{CASBEE}

Comprehensive Assessment System for Building Environment Efficiency (CASBEE) was launched by the Japan Sustainable Building Consortium in 2001. The tool majorly focused on green building certification in Japan and Asia (CASBEE, 2016). BEE (Building Environmental Efficiency) is used to calculate the scores. CASBEE consist of four basic assessment tools:

- "CASBEE for Pre-Design (CASBEE-PD), for projects at a very early stage to help with planning and site selection.

- CASBEE for New Construction (CASBEE-NC), to assess buildings during design and construction stages.

- CASBEE for Existing Buildings (CASBEE-EB), for buildings that have been occupied for at least one year.

- CASBEE for Renovation (CASBEE-RN) to help generate proposals for building upgrades and to assess improvements". (Endo et al, 2007; CASBEE, 2016).

CASBEE utilizes weightings to adjust the esteem tending issues with the quantity measures accessible. Notwithstanding, the weight is connected to every category (quality of service, outdoor environment onsite, indoor environment, resources \& material, off-site environment, and energy) (see Fig 1.3). Each category is streamlined under headings such as serviceability, building thermal load, lightning, and illumination. It also contains sub-issues which are ventilation rate, CO2 monitoring, adaptability of floor plate, etc. (Endo et al 2007; Saunders 2008).

According to CASBEE (2016), results are designed on charts, with the environmental load on and quality. Each category is scored from level 1 to level 5, with level 1 (the lowest point), and 
level 5 (the highest point of accomplishment). The score and rating are displayed in different ways, which makes it more flexible on how the information can be used, also this might lead to a greater potential confusion or clarity of assessment.

\section{Green Star}

Green Building Council of Australia (GBCA) launched Green Star in 2002 to assess the environmental issues relating to design and construction of buildings in Australian. The objective of creating Green Star was to encourage sustainable building development while promoting green building technologies, practice, and operations (GBCA 2009a; NZGBC 2009).

Green Star is a standout amongst the most took after willful building evaluation device created to oblige the requirement for building in hot atmospheres where cooling frameworks and solar shading are of significance (Cole, 1999). Green start consists of four rating tools which are space use, spatial differentiation, conditional requirements and timing of certification. The building accreditation is communicated as various stars: 1-3 Stars (10-44 points; not qualified); 4 Star (45 -59, best practice); 5 Star (60 - 74, Australian excellence); 6 Star ( 75 - 100, world leadership) (GBCA2009d).

\section{SB Tool}

International Green Building Challenge initiative, later named the Sustainable Building Challenge in 1996, set up an energy and environmental tool for both universal and national settings. Initiating from the SBMethod, Green Building Tool (GBTool), was later renamed to Sustainable Building Tool (SBTool) (Bernardi et al., 2017). It was, important to recognize evaluation tool that, through various methodological bases, would have the capacity to dispassionately survey the necessities of the environmental, economic, and social effects of a building during its life cycle. SBTool is based on area and site particular setting factors, and these are used to decline certain weights, and giving establishment information to all environment. The SBTool is a fundamental structure for rating the environmental execution of a building by distributing points for different aspects (iiSBE, 2017).

The SBtool process is managed by IISBE (International Initiative for a Sustainable Built Environment). The evaluation is basically through the aggregate examination counts. The plan is partitioned into two areas: Module A and Module B. The tool does not work with new or redeveloped projects, likewise they can be applicable to various process through the development phases from the pre-design phases, the design phase, the construction phases, and to the operations phases as demonstrated by different results starting from various data inputs. It focuses on seven categories: site selection, project planning and development; environmental loadings; energy and resource consumption; indoor environmental quality; functionality \& controllability of building system; long-term performance; and social and economic aspects (see Fig 1.5). The categories are scored from -1(below typical practice) or from +1 to +5 (good to very high performance). Weighting is at some point can be modified partly by an authorized third party (iiSBE, 2017).

\section{GSAS}

Gulf Organization of research and Development (GORD) in 2009 established Global Sustainability Assessment System (GSAS), as an incorporated and performance-based assessment tool. It was modeled on the best practice from the region drawing from global rating systems such as BREEAM, LEED, CEPAS, CASBEE, GREEN GLOBES and International SB Tool. GSAS consist of eight main categories: Energy; Water; Indoor Environment; Cultural \& 
Economic; Site; Urban Connectivity; Materials; Management and Operations (see Fig 1.6). GSAS scoring is measurable on the scale of -1 to $3(-1,0,1,2,3)$, which signifies a fundamental uniform ordinal scale from negative level (-1) to optimal level (3), and have 1-6 Stars certification that can be achieved (GSAS, 2017).

\section{$S B A T$}

South African Council for Scientific \& Industrial Research (CSIR) developed SBAT. On July 2000 , in the issue of engineering news report, it stated that "the programme has also seen the development of an assessment tool known as the building environmental assessment rating system, which measures the effect of the building have the environment, as well as the various indoor components of the building". The tool derived was known as BEARS (Building Environmental Assessment rating System) which was developed into a current prototype Sustainable Building Assessment Tool (SBAT). SBAT was developed to help set out parameters which adhere to achieve a more sustainable building (Gibberd, 2002).

Sustainable Building Assessment Tool (SBAT) was developed to measure sustainability performances in a building environment. It contain 15 aspects which are arranged around the environmental, social and economic criteria namely: Education; Material \& components; Local Economy; Efficiency; Ongoing Costs; Adaptability; Capital Costs; Water; Access to facilities; Waste; Site; Occupants Comfort; Energy; Inclusive Environments; participation \&control; Health and Safety (Gibberd, 2002).

The performance of each category is measured out of 5 and presented in radar diagram as seen in (Fig 1.7). A concluding assessment is based on 75 indicators which include 15 areas with 5 criteria in each of them (Gibberd, 2002). The 5 criteria are formed by three steps (a) Setting the Project Up, (b) Entering Measurements, and (c) Reading the Report.

A nine stage building lifecycle process was also considered for this tool, which includes: briefing, site analysis, target setting, design, design development, construction, handover, operation and reuse/refurbishes/recycle.

It is not the aim of this research to draw a parallel amongst the assessment tool but to learn from the discourse and to develop a relationship string between the assessment tool while identifying their limits and merits. This creates a new means of perceiving sustainable development and a need for laying out a social criterion sustainable objective based on the projects culture and social demand. 


\section{Methodology}

Table 3.1 Road map for the research

\begin{tabular}{|c|c|c|c|}
\hline \multirow{2}{*}{$\begin{array}{c}\text { AIM } \\
\text { STAGES }\end{array}$} & \multicolumn{3}{|c|}{$\begin{array}{l}\text { To explore and evaluate social criteria of sustainable development and green building assessment tools system that is able to } \\
\text { assist building practitioners to attain a sustainable development. }\end{array}$} \\
\hline & OBJECTIVES & UNDERTAKING & METHOD \\
\hline \multirow{2}{*}{ 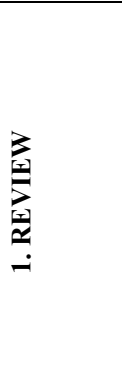 } & $\begin{array}{l}\text { 1) Current views and background information about } \\
\text { the research relating to green building assessment tool }\end{array}$ & $\begin{array}{l}\text { Step 1: Examining relevant literature through } \\
\text { analysis of recently published data (books, journals, } \\
\text { articles etc.) }\end{array}$ & DA \\
\hline & $\begin{array}{l}\text { 2) Examination of current terminologies used in } \\
\text { building assessment tool and social sustainability in } \\
\text { reference to social criteria, to highlight their strength } \\
\text { and weakness. }\end{array}$ & $\begin{array}{l}\text { Step 2: Reviewing relevant literature and } \\
\text { classifying the categories identified }\end{array}$ & DA \\
\hline \multirow{2}{*}{ 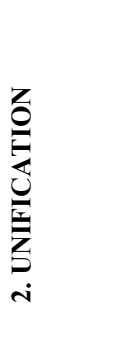 } & $\begin{array}{l}\text { 3) To identify the vital influential categories that affect } \\
\text { the social criteria selections. }\end{array}$ & $\begin{array}{l}\text { Step 3: To conduct a study using a bottom- down } \\
\text { approach on issues relating to social factors of } \\
\text { sustainable development. }\end{array}$ & \multirow{2}{*}{$\begin{array}{l}\text { DA, OBS, } \\
\text { BD }\end{array}$} \\
\hline & & $\begin{array}{l}\text { Step 4: Carrying out an inspection on the building } \\
\text { assessment tool identified in the literature and } \\
\text { observational study on how they function in } \\
\text { operation, while cataloguing them into different } \\
\text { criteria }\end{array}$ & \\
\hline 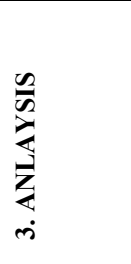 & 4) Establishing and specifying the categories identified & $\begin{array}{l}\text { Step 5: Analysing data gathered from the surveyed } \\
\text { exercise, while using comparative analytical } \\
\text { principle. }\end{array}$ & DA, C \\
\hline \multirow{3}{*}{ 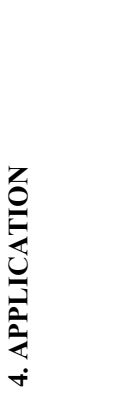 } & $\begin{array}{l}\text { 5) Development of a pre-selected set of categories for } \\
\text { social criteria. }\end{array}$ & $\begin{array}{l}\text { Step 6: Assembling of key components and data } \\
\text { generated from analysis using a top-down approach. }\end{array}$ & \multirow[b]{2}{*}{ DA. TD } \\
\hline & & Step 7: Development of a proposed structure. & \\
\hline & 6) Conclusion & $\begin{array}{l}\text { Step 8: Describing result using relevant data to give } \\
\text { a feedback for future studies }\end{array}$ & DA \\
\hline KEYS & cumented Analysis) OBS (Observation) C (Com & ative) TD (Top-Down) $\quad$ BD (Bottom - Down) & \\
\hline
\end{tabular}

Seven green building assessment tools were selected, on how best they fit the objective of the study. Green building assessment tools were studied while addressing it through the social criteria of sustainable development. Literature documentation was used as a feature of discussion to support the study of the research objective, taking into consideration the criteria of sustainable development (environmental, social and economic) and social categories from experts. Qualitative analysis was piloted as a strategy for sorting each sustainable criteria. 
Taking into consideration social criteria and the weight scores given by these tools to the categories identified.

The category selection of social criteria in sustainable development was based on interpretation of research documents from authors using a bottom- down approach, where each indicator identified had features contributions from experts relating to the subject. To identify the categories in the green building assessment tool using the triple bottom line framework, a statistical documented analysis was adopted using a bottom-down approach to conduct an overview of green building assessment tool from 5 geographical regions (Europe, America, Asia, Gulf Region, Africa) based on their popularity and influences.

Then based on literature presented in GBAT and social criteria a comparative study was conducted to limit the research focus to social criteria, in order to help define the pre-selected sets of categories that was generated. Therefore in this study, the social criteria categories were adopted.

\section{Findings and Analysis}

Social criteria of sustainable development are defined as improving and maintaining the wellbeing of individual of present and future generations (Chiu, 2003). Social criteria of sustainable development can also be referred to as social sustainability. Social sustainability is set to be achieved when an environment is created to work harmoniously, while reducing the social inequalities and difference, thereby promoting and improving the quality of life (Enyedi, 2002). Generally, social sustainability is viewed as a basic quality or objectives of social orders for development in foreseeable future. The basic quality or objectives consist of a different categories and factors: equity, participation, satisfaction, basic needs, social cohesion, income, well-being, social justice, employment, safety, and education. However, because of the absence of a coordinated applied system and a far-reaching meaning of the idea of social sustainability the thought stays ambiguous to some degree (Littigi \& Griebler, 2005; Colantonio, 2009; Colantonia \& Dixon, 2011, Jaeger et al, 2011; Ahman, et al 2013; Weingaertner \& Moberg, 2014). With this instance, green building assessment tool has been duly been affected with a single faced assessment tool developed aimed at attaining sustainable development in the building environment.

Several of literature sources has endeavoured to address the conceptualization of social sustainability in sustainable development from different disciplines such as sociological perspective, planning perspective, and political perspective. However, despite the difference, some of the factors overlap each other to give a certain character to the definition of social sustainability (Liu, 2017).

Table 4.1 shows a list of authors and organizations with literature that reveals various understanding and provides a basis for what social factors/theme/categories of sustainable developments are represented. This development would aid to give an in-depth understanding from the expert viewpoint in order to identify the basis of the social character defined in sustainable development. The table identifies social classification and theme in social indicator sets as the UN Commission for Sustainable development, EU Sustainable Development, and OECD Social indicators evaluate (UNCSD, 1996; UNDESA. 2001; UNBESDA, 2007; Eurostat, 2007; OECD, 2016). These indicators of sustainable development defined in accordance with the vision, policy, and goal of sustainable development. 
Table 4.1 Authors and Organisation Definition of Social Factors in Sustainable Development

\begin{tabular}{|c|c|}
\hline \multicolumn{2}{|c|}{ Concept of Social Factors As Described by Authors And Organizations } \\
\hline Authors /Organizations & Social Factors/ Classifications/ Themes. Categories \\
\hline $\begin{array}{l}\text { UN Commission for Sustainable Development } \\
\text { (UNCSD, 1996) }\end{array}$ & $\begin{array}{l}\text { - Combating poverty } \\
\text { - Sustainable demographic dynamic } \\
\text { - Protecting human Health } \\
\text { - Promoting human settlement } \\
\text { - Promoting education, public awareness and training }\end{array}$ \\
\hline Sachs (1999) & $\begin{array}{l}\text { - Equitable income } \\
\text { - Social homogeneity } \\
\text { - Access to goods } \\
\text { - Service and employment }\end{array}$ \\
\hline Polese and Stren (2000) & $\begin{array}{l}\text { - Social integration } \\
\text { - Cultural diversity } \\
\text { - Equity }\end{array}$ \\
\hline $\begin{array}{l}\text { UN Commission of Sustainable Development } \\
\text { (UNDESA, 2001) }\end{array}$ & $\begin{array}{l}\text { - Equity } \\
\text { - Health } \\
\text { - Education } \\
\text { - Housing } \\
\text { - Security (combating crime) }\end{array}$ \\
\hline McKenzie (2004) & $\begin{array}{l}\text { - Equity } \\
\text { - Diversity } \\
\text { - Quality of life } \\
\text { - Interconnectedness democracy government }\end{array}$ \\
\hline Littig \& Grießler (2005) & $\begin{array}{l}\text { - Basic need and quality of life } \\
\text { - Social justice } \\
\text { - Social coherence }\end{array}$ \\
\hline $\begin{array}{l}\text { UN Commission for Sustainable Development } \\
\text { (UNDESA, 2007) }\end{array}$ & $\begin{array}{l}\text { - Poverty } \\
\text { - Governance } \\
\text { - Health } \\
\text { - Education } \\
\text { - Demography }\end{array}$ \\
\hline $\begin{array}{l}\text { EU Sustainable } \\
\text { (Eurostat, 2007) }\end{array}$ & $\begin{array}{l}\text { - Public health } \\
\text { - Social inclusion } \\
\text { - Demographic changes } \\
\text { - Good governance }\end{array}$ \\
\hline Chan \& Lee (2008) & $\begin{array}{l}\text { - Social infrastructure } \\
\text { - Availability of job opportunities accessibility } \\
\text { - Townscape design } \\
\text { - Preservation of local characteristics } \\
\text { - Ability to fulfil psychological needs }\end{array}$ \\
\hline Cutchill (2009) & $\begin{array}{l}\text { - Social capital } \\
\text { - Social infrastructure } \\
\text { - Social justice + equity } \\
\text { - Engaged governance }\end{array}$ \\
\hline Colantonio (2008) & $\begin{array}{l}\text { - Basic need } \\
\text { - Equity } \\
\end{array}$ \\
\hline Vavik \& Keitsch (2010) & $\begin{array}{l}\text { - Poverty } \\
\text { - Illiteracy } \\
\text { - Access } \\
\end{array}$ \\
\hline Dempsey et al (2011) & $\begin{array}{l}\text { - Social equity } \\
\text { - Sustainability of community }\end{array}$ \\
\hline Vallance, et al (2011) & - Equity \\
\hline Woodcraft et al (2011) & $\begin{array}{l}\text { - Social and cultural life } \\
\text { - Social amenities } \\
\text { - System for citizen engagement } \\
\text { - Space for people and place to evolve }\end{array}$ \\
\hline Murphy (2012) & - Equity \\
\hline
\end{tabular}




\begin{tabular}{|c|c|}
\hline & $\begin{array}{l}\text { - Awareness of sustainability } \\
\text { - Participation } \\
\text { - Social cohesion }\end{array}$ \\
\hline Ahman, et al (2013) & - Equity \\
\hline Davoodi (2014) & $\begin{array}{l}\text { - Social interaction in place } \\
\text { - Architectural identity } \\
\text { - Social security } \\
\text { - Hierarchy } \\
\text { - Participatory design } \\
\text { - Flexibility } \\
\end{array}$ \\
\hline OECD Social Indicators (OECD, 2016) & $\begin{array}{l}\text { - Self sufficiency } \\
\text { - Equity } \\
\text { - Health status } \\
\text { - Social cohesion }\end{array}$ \\
\hline Eizenber and Jabareen (2017) & $\begin{array}{l}\text { - Equity } \\
\text { - Safety } \\
\text { - Urban form } \\
\text { - Eco- prosumption }\end{array}$ \\
\hline
\end{tabular}

Becker and Jahn (1999), expresses social sustainability as long-term relationships among nature and society which lead to the feasibility of society. Sachs (1999), was of opinion that social sustainability lays on the fundamental estimations of equity and democracy. Meanwhile, social sustainability as a development occurs by balancing the evolution of a civil society, where the development should result in a rich environment (Polese \&Stren, 2000). Biart (2002) was of opinion that social sustainability embraces the nominal and acute social requirements for the long-term sustainability of societies. Therefore to achieve social sustainability the long-term survival of society should be clearly recognized.

Social sustainability was also defined "as a positive condition within communities and a process within counties that can achieve that condition" (McKenzie, 2004), thereby describing social sustainability as a progression rather than a goal that is to be achieved in the future. They indicated five principal themes: equity, diversity, quality of life, interconnectedness and eventually democracy \& government. Littig and Grießler (2005) investigated the lack of sociological theory in the concept of social sustainability, where it was highlighted that social indicators and policy objectives in the discourse of social criteria. They suggested that social sustainability indicators are to be derived from sociological theories for better understanding. They classify the set of indicators into three aspects namely: (i) Need and quality of life - an aspect that relates to basic material needs and fulfillment such as individual income, poverty, unemployment, education, income distribution, housing condition, security, health, housing satisfaction and the environment. They advised that these features are to be met to provide basic need and quality of life to individuals or communities. (ii) Social Justice - this set of indicator describes the equality of opportunities, where justice regarding the distribution of income and equal opportunities are offered towards the quality of life, education, gender, and participation in the society. (iii) Social Coherence - this set of indicator describes there unity among different social groups, where there is an integration of a social network, activity involvement, solidarity and tolerant attitude. Colantonio (2008), advocated two basic concepts: the basic need- focuses on the physical aspect of life and society (health, housing, and food); equity - focuses on the social difference and other concepts such as (equal access to services and education).

More factors that affect social sustainability urban development projects were highlighted (i) Provision of social infrastructure - this aspect describes the provision of physical infrastructure such as public facilities which delivers services that are locally based and creates an avenue for social interaction.(ii) Availability of job opportunities - this aspect describes the provision of 
employment, where employment provides the general income of an individual and the working area that provides a room for social connexion and interaction. Thereby improving the social well-being of the citizens. (iii) Accessibility - it defines the provision of convenient and proper access in crucial live, work and leisure activities that do not involve traveling a lot. (iv) Townscape design - this aspect entails the provision of townscape designs that are visually attractive, functional and able to promote social interaction within the community. (v) Preservation of local characteristics - it entails the ability to preserve/conserve properly the physical and social/local characteristic for the future generation. (vi) Ability to fulfill psychological needs - this aspect entails providing a safe and secure environment for the community to participate and meet their needs and desires (Chan and Lee, 2008).

Cuthill (2009), employs four vital factors of classifying social sustainability namely: Social capital - this describes the advancement of social linkages and a logic of social responsibility. Social infrastructure - this entails offering facilities that discuss the limit with regards to support to the general public. Social justice \& equity - giving of even-handed access to fundamental wellbeing services and employment, particularly for defenceless people. Engaged governance - entails the promotion of bottom-up (individual elements to a whole) and participatory democracy within the society. Dempsey (2009), identifies the concept of social sustainability into two core notions social equity (equal use to service, facilities, and opportunities) and sustainability of community (social interaction/social network, social participation, stability, sense of pride in local place, security, and safety). Vavik \& Keitsch (2010), identifies three goals of social criteria of sustainable development: poverty (encouraging incorporation by giving essential needs); illiteracy (encouraging easy access to education); access (encouraging access to partake in decision making). Meanwhile, Woodcraft et al (2011), defines social sustainability as a process where a rich society is created by an exhaustive indulgent of people's wants and needs. This includes the process of creating a sustainable society that promotes social and cultural life, social amenities, a system for residents to participate, places and space for people to develop.

Vallence et al (2011), suggested a social conceptualization based on three aspects: Development - addresses the basic needs, education, equity and access to influential decision makers. Maintenance - addresses the up keeping of social-cultural features that affect changes and how people react to changes. Bridge - underlines the behavioral change keeping in mind the end goal to accomplish bio-physical environmental objectives. Murphy (2012) employs four conceptual classifications of social criteria of sustainable development namely: equity, participation, awareness for sustainability and social cohesion that links social and environmental policy objectives. Ahman et al (2013), sees equity as the main concept of social sustainability, however, they categorized equity into several aspects (social cohesion, education, social capital, diversity, sense of place, quality of life and integration.

From the architectural design perspective, (Davoodi et al., 2014) observed six principles of social sustainability and its indicators namely: Social interaction in place - design of a place which increases social interaction within the building. Architectural identity - building design rooting from the culture and history of the society. Social security - increasing the sense of security within the building, Hierarchy - using different hierarchy system to increase the sense of order within the society. Participatory design - engaging in participatory design programs as a social process of design which helps play a key role in the society. Flexibility - flexibility in architectural design forms to conform to the rate of economic \& social changes and technological advancement. Eizenberg and Jabareen (2017), suggested an inclusive social conceptual framework of social sustainability, which comprises of equity, urban form, safety, and eco-presumption. 
Conclusively social criteria of sustainable development theme/categories appear to be a very diverse topic. According to (Demspey, 2009; Bostrom, 2012; Eizenberg \& Jabareen, 2017 and Liu et al 2017) they described social criteria of sustainable development as it varies from abstract (social justice) to concrete (equity), from subjective (satisfaction and well-being) to objective (health and income), from non-physical (quality of life and safety) to physical (housing, urban custom and environmental value), from individuals (activities) to social relations (social capital \& cohesion), and from substantive (need) to procedural (participation and empowerment) which some of them were observed in Table 3.1 above.

\section{GBAT and Social Criteria}

With the advent of sustainable development, numerous green building assessment tool has been coordinated to aid the environmental criteria with a few considering the social criteria in decision making and design practice. This section explores the information building practitioners require to attain a socially sustainable stage using green building assessment tool while formulating the decision regarding sustainable development.

In this section seven assessment tool in developed and developing countries were identified and examined in details. Developed nations, possess of most basic human needs and most likely be surpassed in many cases (Loh, 2000). Therefore in these developed countries they only try to maintain an assured standard of living while decreasing the resources diminution and environmental alterations (DETR, 1994), assessment tool such as BREEAM, LEED was established to curb this aspect. Meanwhile, in under-developed nations, with an average standard of living way lower compared to developed nations, the basic human need has not been attained in many cases. This, therefore, stipulates a need for a development that aims, at addressing the basic need while avoiding the undesirable impact of the environmental factors.

Sustainable development which is attributed to three basic criteria, with the social criteria been as important as environmental and economic criteria in decision making. Regarding numerous studies surrounding green building assessment tool and its environmental and social impacts, it has witnessed a clear neglect of social criteria of sustainability. Where the environmental attributes such as energy, material selection, water efficiency etc. largely emphasizes the impact of these factors on the building and. Therefore it can be said that social sustainability aspect and its indicators have been neglected were individual understanding and perception within the building remains void or negligible.

In order to examine how green building assessment tool addresses the social criteria of sustainable development, the following figures (4.1-4.7) illustrated the weighting system given to the three criteria of sustainable development with an emphasis on the social criteria. With some credit points allocated to procedural, which was highlighted in each assessment tools. These are related to authorizing, responsible construction, and integrative process credits. They generally have an indirect influence on one or more of the sustainable development criteria. 


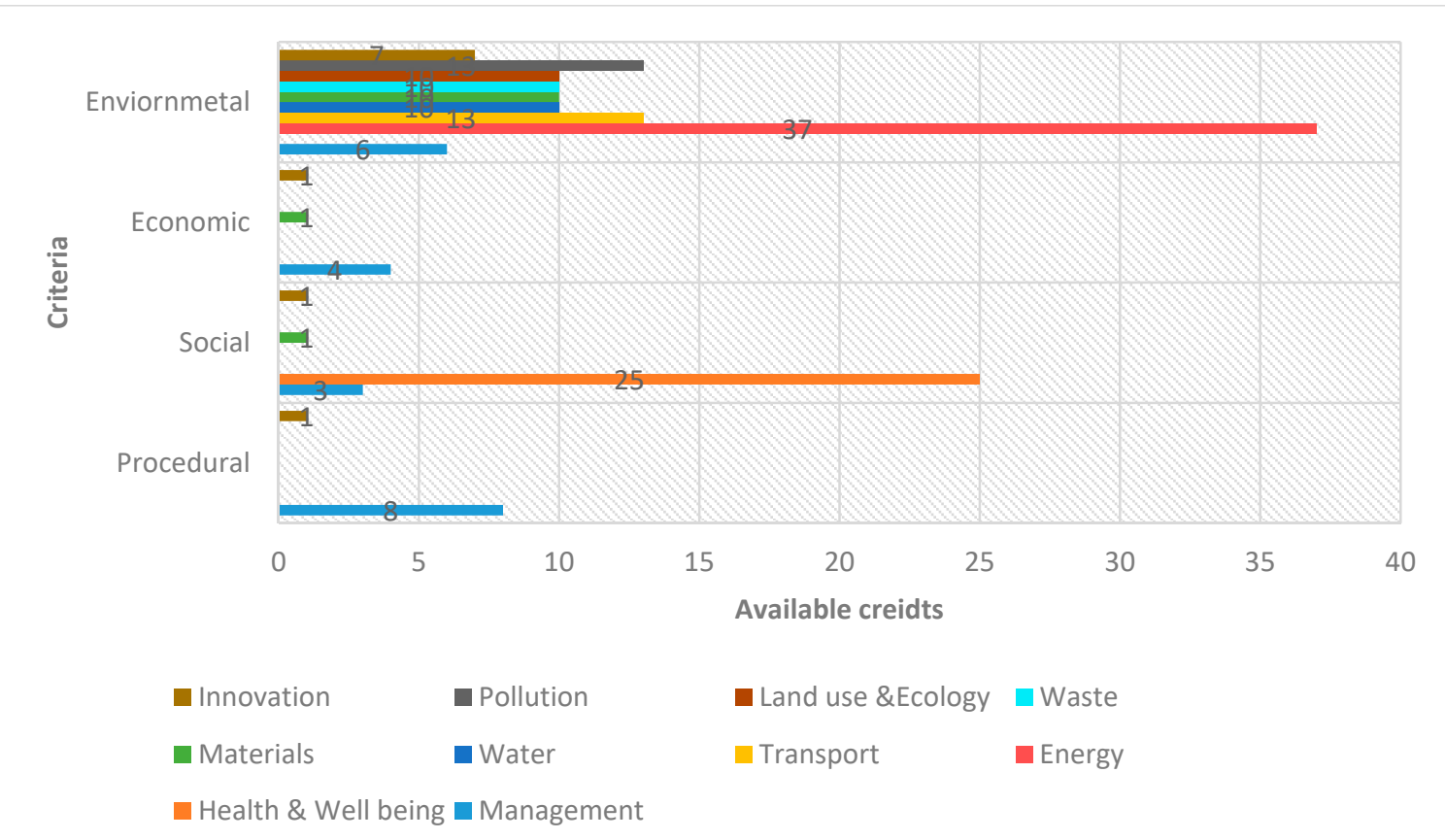

Figure 4.1. BREEAM credit weight for Environmental, Social and Economic criteria

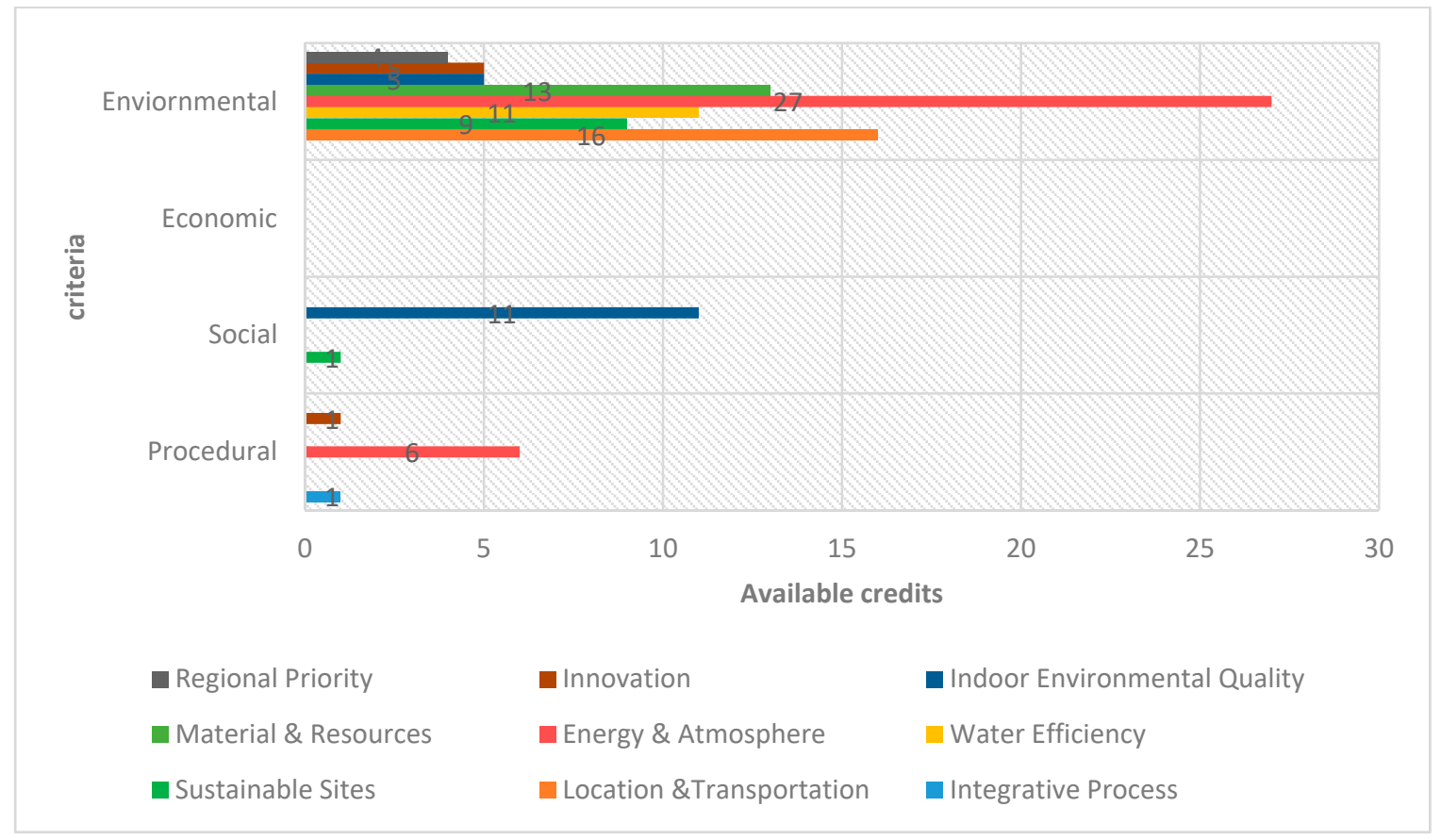

Figure 4.2. LEED credit weight for Environmental, Social and Economic criteria 


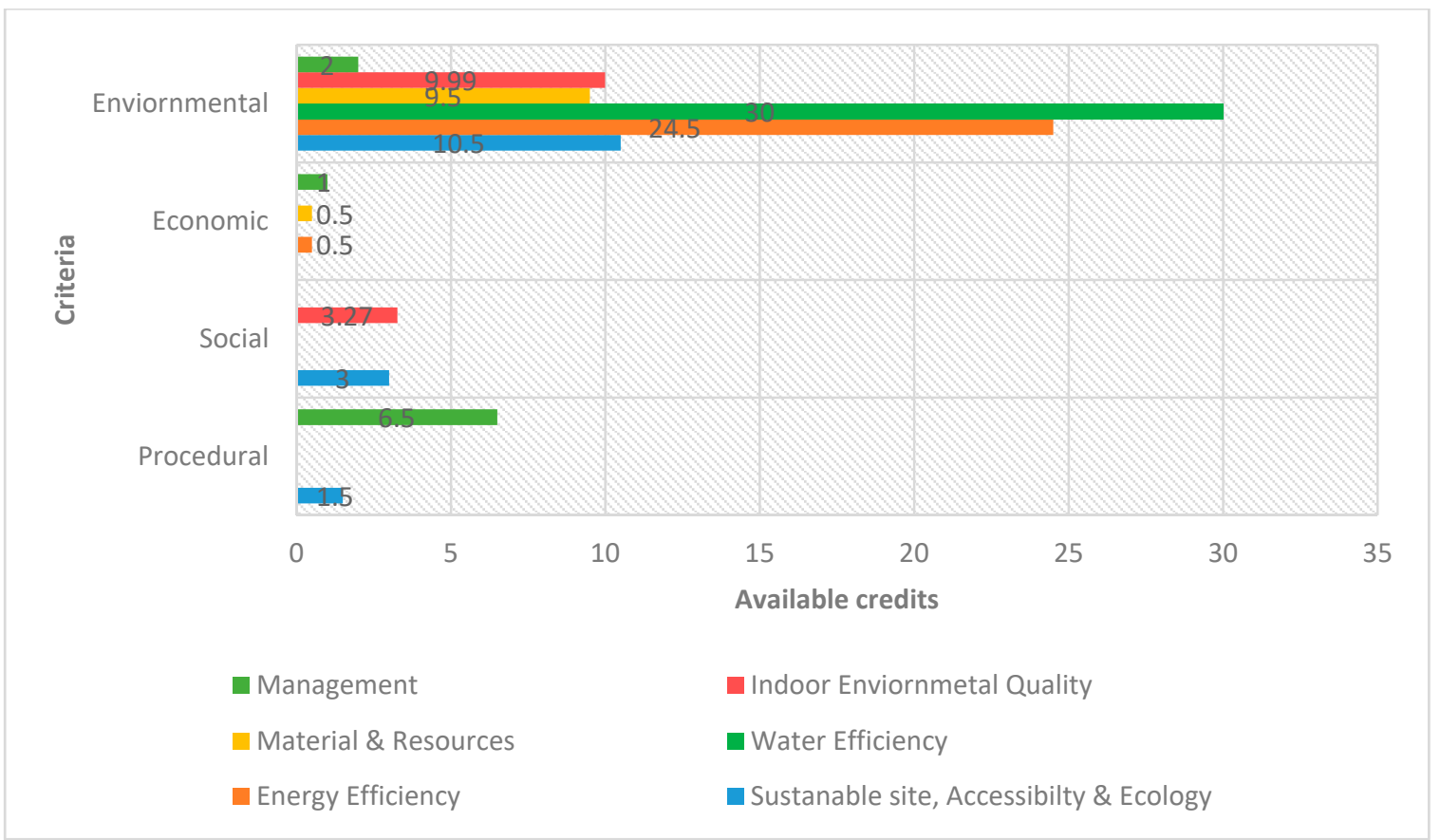

Figure 4.3. CASBEE credit weight for Environmental, Social and Economic criteria

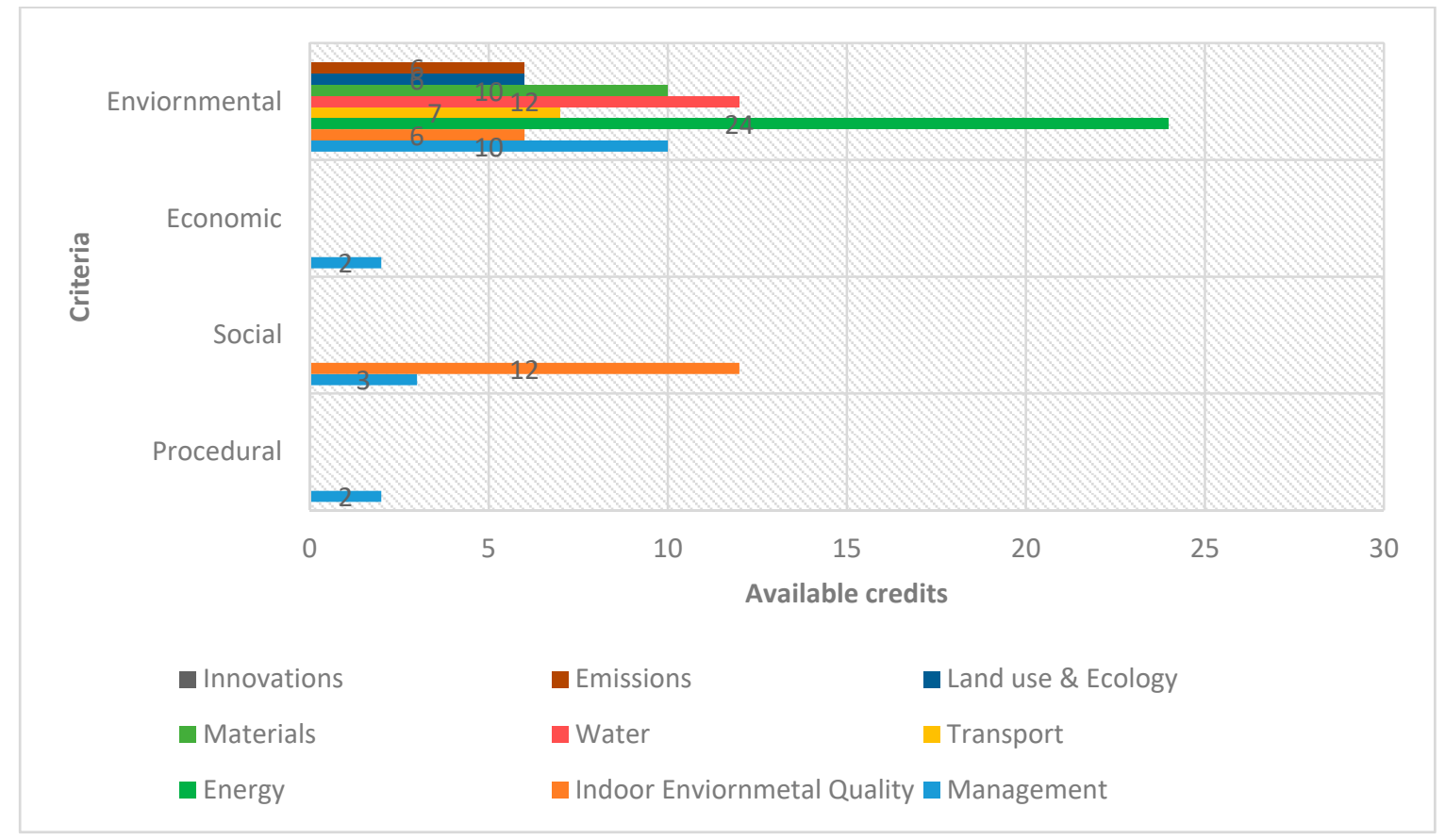

Figure 4.4.GREEN STAR credit weight for Environmental, Social and Economic criteria 


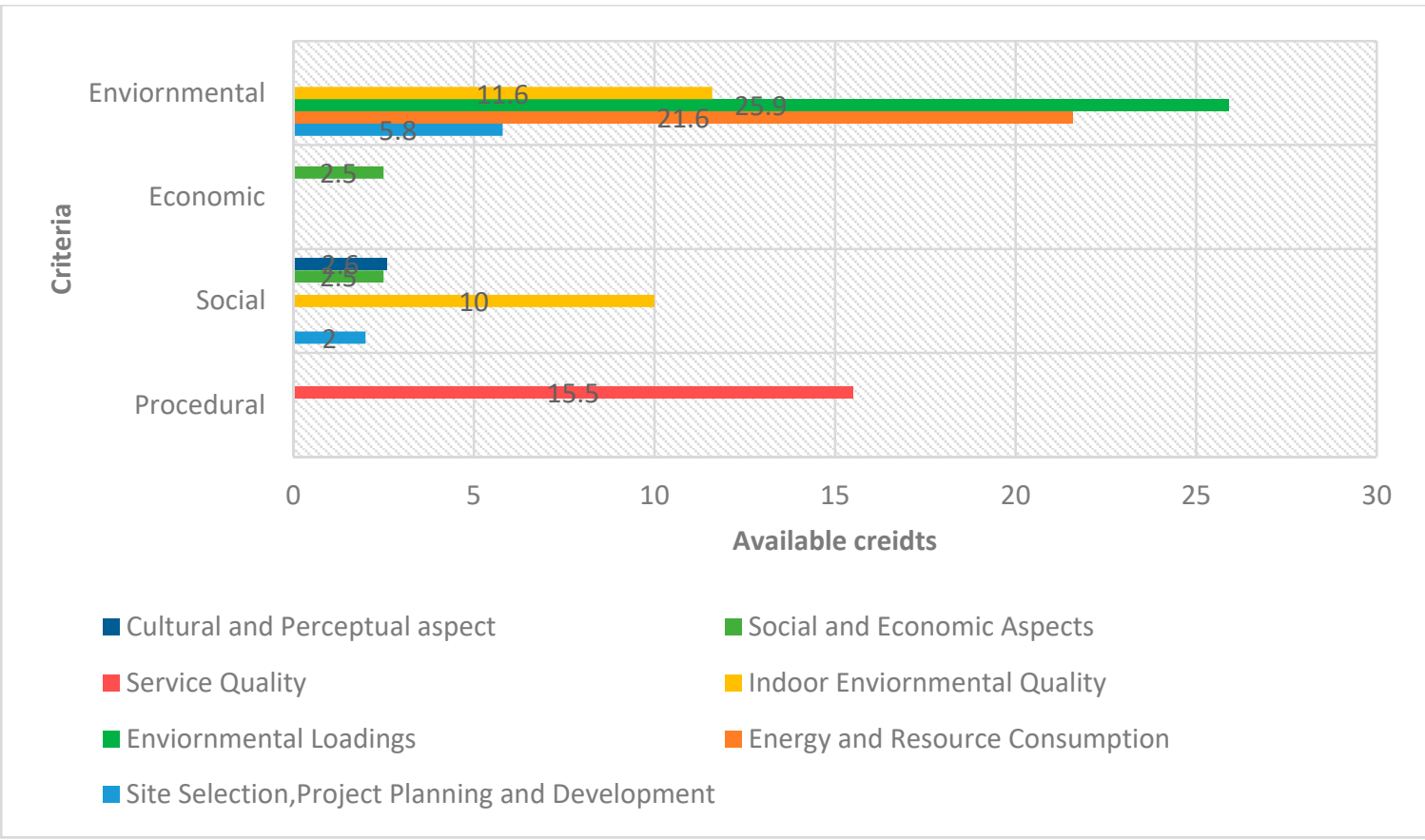

Figure 4.5.SBTool credit weight for Environmental, Social and Economic criteria

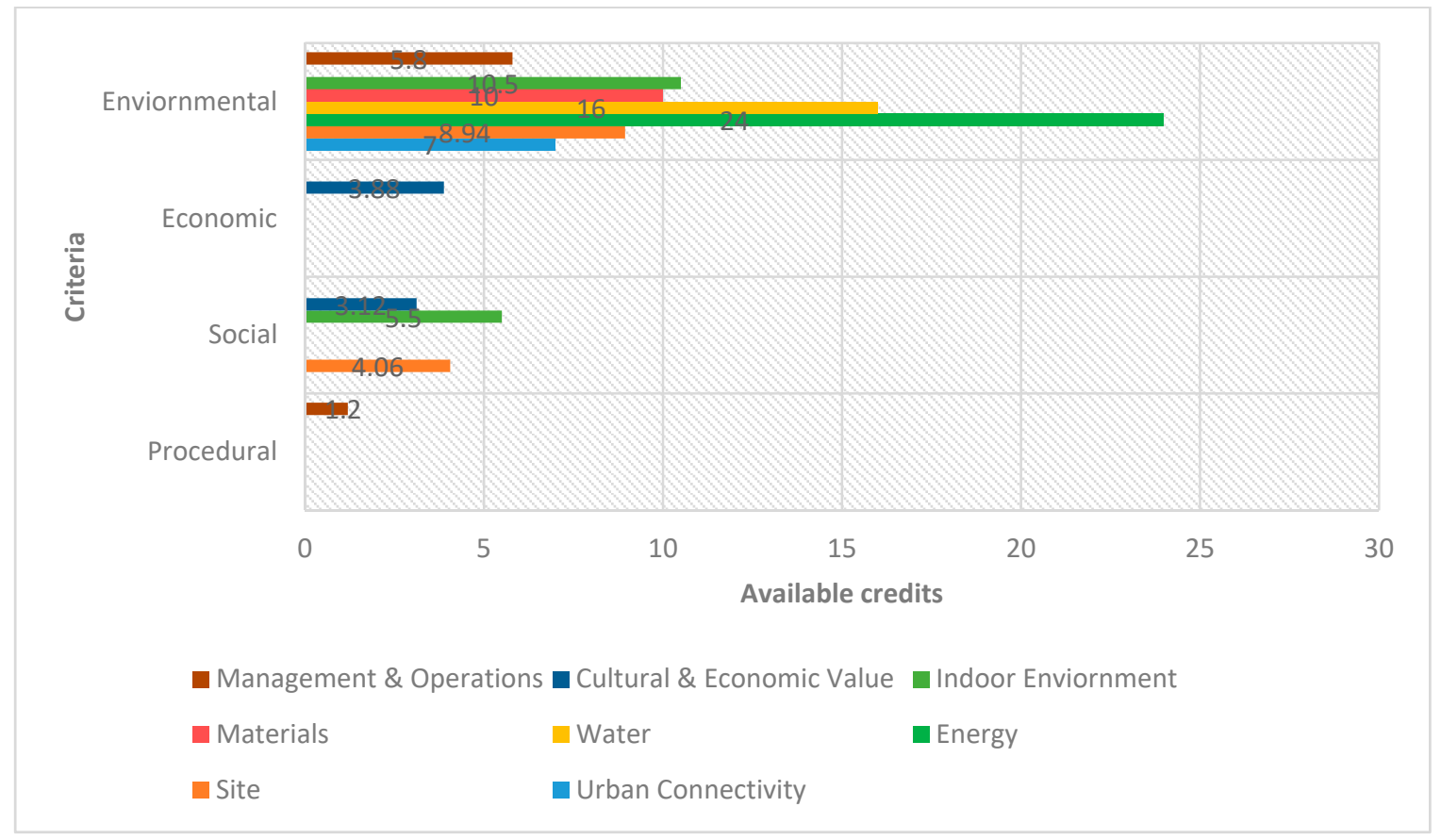

Figure 4.6.GSAS credit weight for Environmental, Social and Economic criteria 


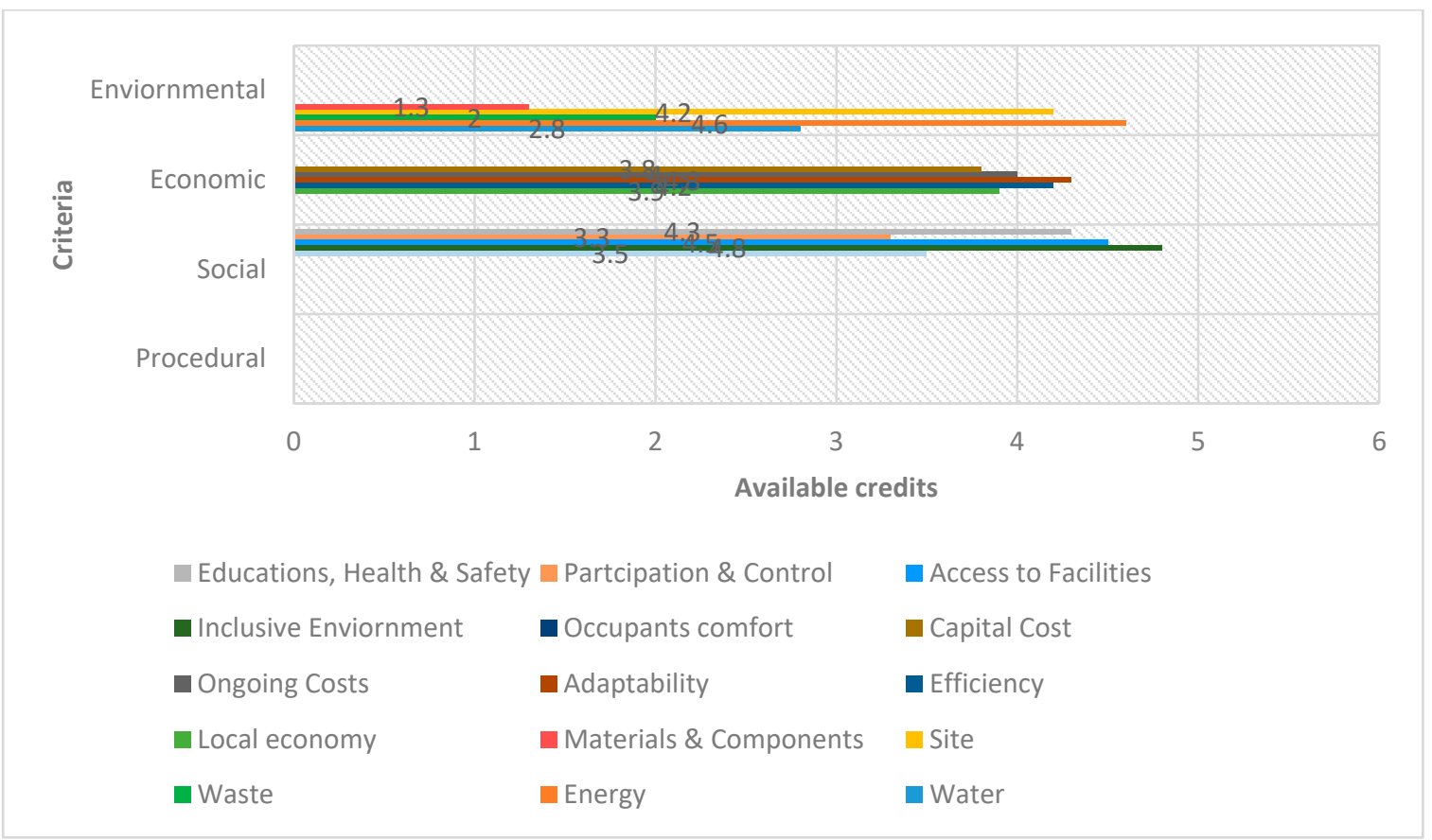

Figure 4.7.SBAT credit weight for Environmental, Social and Economic criteria

The BREEAM International 2016 New Construction assessment tool addresses three criteria (environmental, social and economic) with an uneven weight point. It can be observed that six of the assessment tool give more importance on the environmental criteria while only SBAT has the social criteria as its highest weight of point. This, therefore, describes that majority of the assessment tool is environmentally driven rather than sustainably oriented, as argued by (Cole, 2005; Berardi, 2013; Ameen, Mourshed \& Li, 2015; Sharifi \& Murayama, 2013; Komeily \& Srinivasam, 2015) where environmental aspects are dominant.

In respect to the social criteria, this aspect has been given less consideration in green building assessment tool decision-making process and weight allocation. SBAT has the highest point allocation to social criteria given it a total of 36.7\%, BREEAM allocates 19\%, GB Tool allocates $15 \%$, LEED assigns $11 \%$ and the rest which were below $10 \%$ weighting point. With Green Star assigning 9.8\%, and CASBEE allocating 6\%. This shows a pattern where a neglect of the social aspect of sustainable developed has been neglected majorly in developed countries. It was noted that in developed countries a pattern of the design approach is driven by the project decision where the environmental aspects are considered and brought up before the social aspects. Also, LEED, BREEAM, CASBEE, SBTool and Green Star address the social aspect through neighborhood rating system rather than building system (Awadh, 2017). However, the design for a socially oriented building is not always in question, due to the fact that, the sustainable practices are compelled by the certification rather than looking at the operational phases with the social aspect inclusive. It must be noted that in the Middle East with GSAS, cultural and economic value are identified as indicators. This shows a trend where the social aspect is being considered due to the cultural difference within the region.

According to (Komeily \& Srinivasam, 2015) tools such as LEED, BREEAM, and CASBEE, Green Star and SBTool function on a methodology that practically considers the physical and material properties of the built environment. A noteworthy challenge of such tools is its inability to extensively account for a detailed prerequisite strategy for the different social context. Where the tools are majorly marketing driven oriented and developers embark on pursuing points (Komeily \& Srinivasam, 2015). Existing studies revealed that developers of LEED project 
indulgence criteria with higher point weighting (Sharifi \& Murayama, 2013). In this way, it is conceivable that those tool mentioned above are used to guarantee the selling rate of a community as opposed to its sustainability. The majority of the assessment tool is expert driven and do not sufficiently involve a comprehensive assessment of stakeholders (Sharifi \& Murayama, 2013; Komeily \& Srinivasam, 2015). Berardi (2011) stated that to address the social criteria in sustainable development it involves an appropriate design which relates the building to its neighborhood.

A clear-cut comparative analysis between assessment tools in connection to sustainable aspects has been piloted to additionally introduce the varieties between the green building assessment tools, with the assessment tools generally sharing almost same credit sets, the comparison would be parallel presented.

\section{Result of Analysis}

The social criteria as one of the sustainable development arms. SBAT possess the highest weight point for this criterion in its assessment tool $36.7 \%$, its highlights water, inclusive environment, access to facilities, health and safety participation\& control and education, as key indicators. Indoor Environmental Quality is highly encouraged in all the assessment tool looking through the comfort, health and safety aspect of the occupants within the building. Table 5.1 shows the social categories considered in the GBAT analyzed, and figure 5.1 shows the criteria percentage in all assessment tool analyzed.

Due to the fact that, developed nations possess most of the basic human needs, social criteria of sustainably developed in these nations have not been extensively analyzed, with LEED and CASBEE most specifically having the least allocated percentage with $11 \%$ and $6 \%$ respectively. However, for developing nations where the human need and standard of living are below average, SBAT encourages social criteria with a higher percentage $(36.7 \%)$ to aid sustainable development within the region.

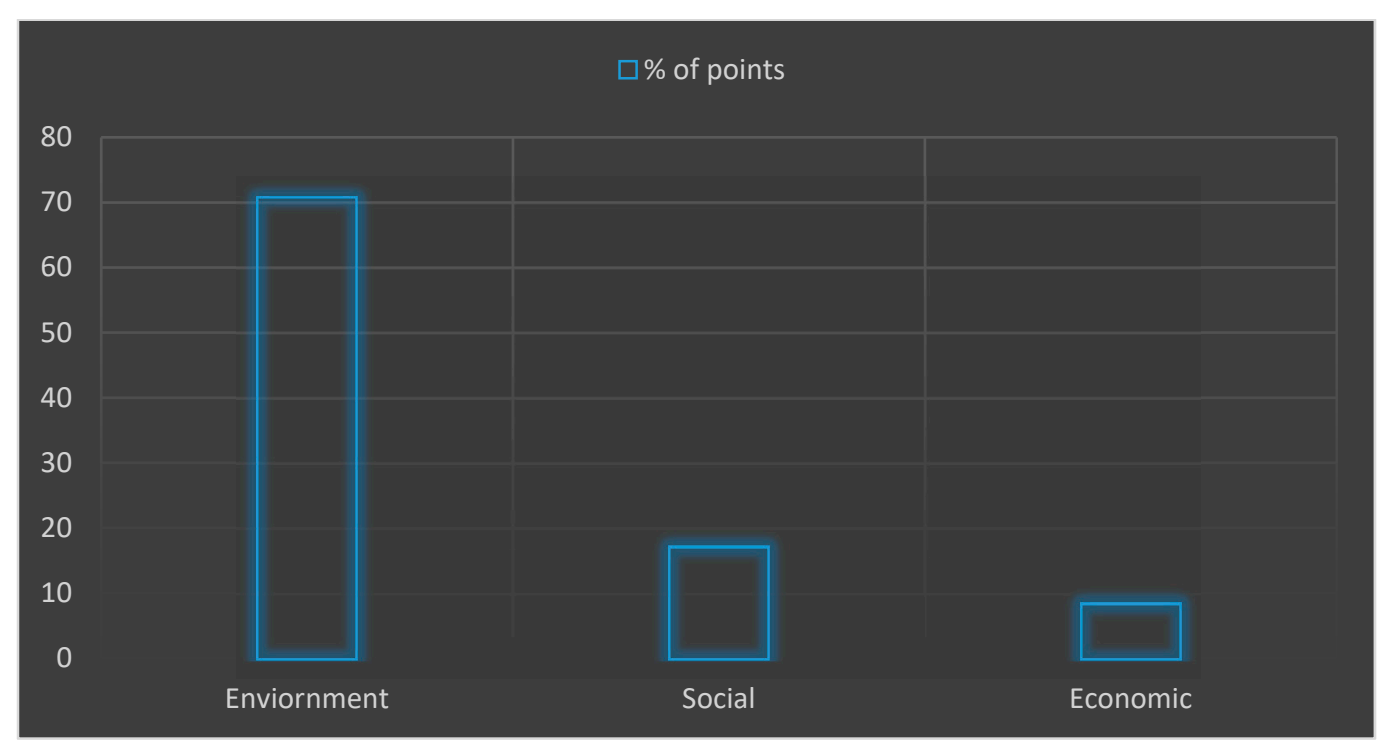

Fig 5.1. Result of BREEAM, LEED, CASBEE, GREEN STAR, SBtool, GSAS and SBAT 
Table 5.1. Social criteria credits for GBAT

\begin{tabular}{|c|c|c|c|c|c|c|c|}
\hline Categories & BREEAM & LEED & CASBEE & GB Tool & Green Star & GSAS & SBAT \\
\hline $\begin{array}{l}\text { Sustainable site } \\
\text { \& Accessibility }\end{array}$ & & $\checkmark$ & $\checkmark$ & $\checkmark$ & & $\checkmark$ & $\checkmark$ \\
\hline $\begin{array}{l}\text { Indoor } \\
\text { Environmental } \\
\text { Quality }\end{array}$ & $\checkmark$ & $\checkmark$ & $\checkmark$ & $\checkmark$ & $\checkmark$ & $\checkmark$ & $\checkmark$ \\
\hline Water & & & & & & & $\checkmark$ \\
\hline $\begin{array}{l}\text { Education, } \\
\text { Health \& Safety }\end{array}$ & $\checkmark$ & & & & & & $\checkmark$ \\
\hline $\begin{array}{l}\text { Participation \& } \\
\text { Control }\end{array}$ & & & & & & & $\checkmark$ \\
\hline Management & $\checkmark$ & & & & $\checkmark$ & & \\
\hline Innovations & $\checkmark$ & & & & & & \\
\hline $\begin{array}{l}\text { Cultural \& } \\
\text { Economic value }\end{array}$ & & & & & & $\checkmark$ & \\
\hline
\end{tabular}

When it comes to the social aspect of sustainable development, indoor environmental quality is first to be accounted for in most green building assessment tool (see table 5.1), where indoor environmental quality entails the comfort, air quality, view and lighting within the building. Sustainable site and accessibility are highly encouraged in LEED- 10\%, CASBEE- 15\%, SBTool- $7.8 \%$, GSAS- $13 \%$ and SBAT- $8.7 \%$, where this aspect tends to help encourages interaction with the environment, passive recreation, physical activities and social interaction. Also, this aspect helps improve and educate the tenants about the implementation of sustainable design features to their buildings. SBAT seems to be more demanding when it comes to education, comfort, and participation with a total sum of $11.1 \%$, due to the lack of social credibility within the region. Therefore the tool encourages a higher weight pointer for this aspects.

The difference between the assessment tools are related but not limited to prioritizing aspect that affects their region; emphasizes on weight pointers that affect their region; considering various credits that are interrelated. From literature observed, there are enormous social criteria categories (see table $4.1 \& 5.1$ ). 


\section{Proposed Structure}

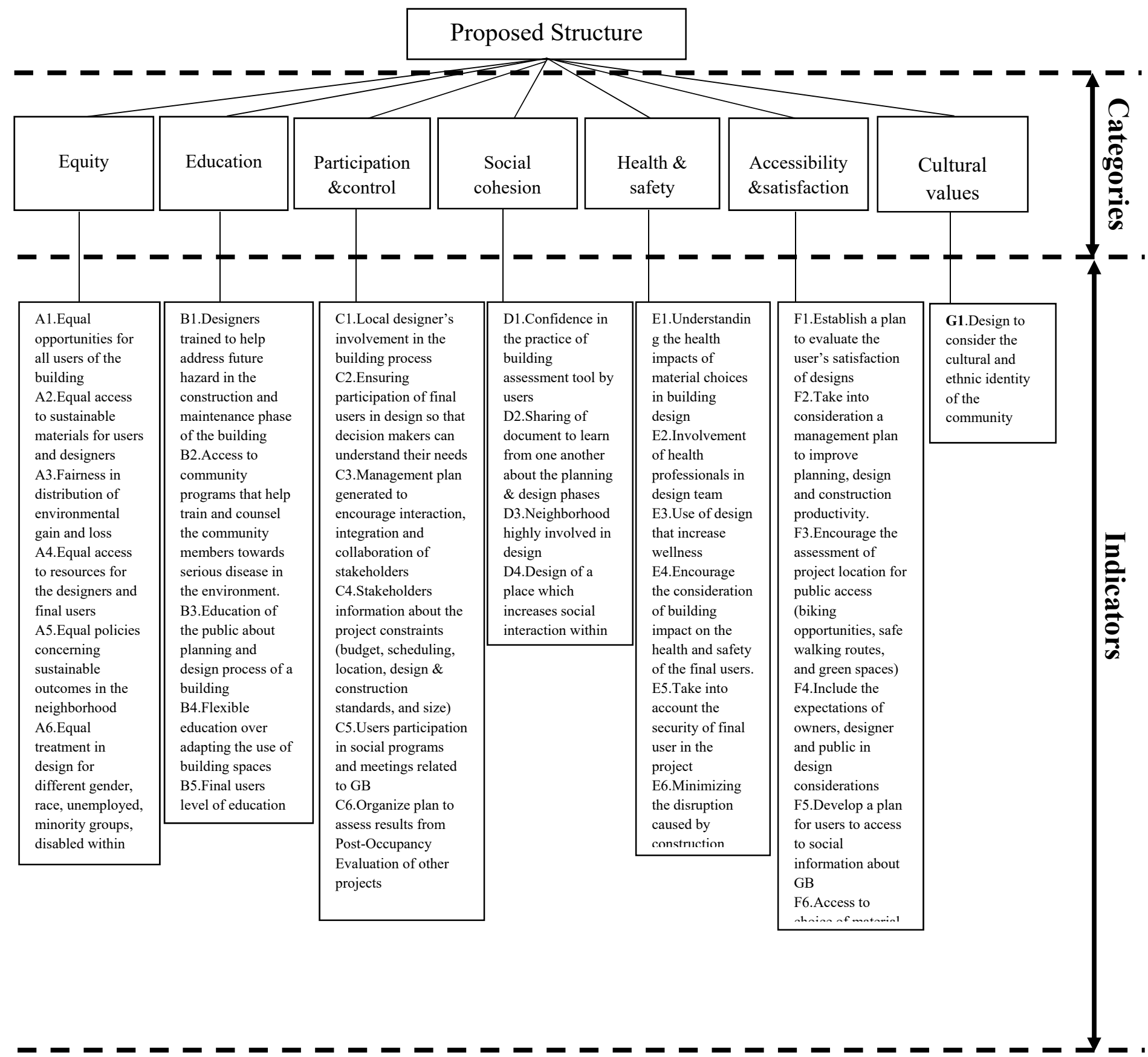

Fig 6.1. Proposed structure of social criteria for assessing in green building

The central aim of the proposed category and indicator set is to provide a Delphi panel of experts with an infrastructural category and indicator as a start-up point from which they would be able to filter and deliberate on, in order to create a list of applicable category and indicator set for social criteria in green building assessment tools. The proposed categories are illustrated in fig 5.2 , they are outcomes of the comparative study which covers well known green building assessment tool and social sustainability theories in sustainable development. 


\section{Conclusion}

In this paper, a synopsis of the green building assessment tool in assessing the social aspect of the building was presented. Green building assessment tool demonstrates the need for adopting an assessment tool to compare and contrast the level sustainable development in buildings, where social criteria merit a particular attention. However, over the last few years, the assessment tools have failed to underline the social criteria, with specific categories and indicators to meet. This research, therefore, gives a summary of the relationship between green building assessment tool and the social criteria of sustainable development. The aim of this paper based on the proposed set of categories was to explore different kinds of social sustainability data which would be adopted for the assessment of social criteria operations in green building assessment tools. The categories were adopted from well-known social sustainable reports and green building assessment tools.

The study shows that SBAT system gives the highest weighting point of the social aspect, while LEED, BREEAM and other prioritize the environmental aspect. Achieving social criteria under LEED and CASBEE system is the most lenient. BREEAM, GSAS, Green Star and SBTool system are not quite rigorous while SBAT is the most rigorous. This productive comparison demonstrates the need to concentrate on the growth towards attaining sustainable development and not aiming certification within a different region. It also depicts a difference in social character between regions, with developing and undeveloped nations focusing majorly on the social criteria as direct impact factor to aid sustainability, the developed nation careless of the social criteria.

From research gathered social criteria of sustainable development are still rather underexposed and under-theorized in the green building assessment tool. With diverse perceptive to social sustainability which produced 73 social criteria categories (see table 4.1), with a larger portion of them repeated in each other's classification. This makes it difficult to acquire a vibrant definition or comprehension of the social criteria. Likewise, an absence of contextualization confines the grasp and elucidation of social criteria into green building assessment tool. This paper aimed to construct a holistic understanding into social sustainability and green building assessment tool. The comparative analysis also indicates that the social criteria of sustainable development can be evaluated by sustainability assessment tools. However, as previously stated, the sustainability assessment depends on a few key categories and indicators. Thus the available data from green building assessment tool have conditioned the evaluation of 8 social criteria categories (see table 5.1). Thereby the paper proposed seven sets of social criteria categories (health \& safety; participation \& control; education; equity, accessibility \&satisfaction; social cohesion; and cultural values (fig 6.1)). The presented analysis demonstrates the importance of the social criteria in design project regardless of its region. Green building assessment tool was developed to help obtain sustainable developed and is not limited to the environmental criteria alone. It should include an overall criteria base system which would aid decision-making, consistency towards setting out a sustainable design focused team. The results gathered from the analysis will help define the benchmarks of best practice, which will be useful in preparing the social criteria assessment tool guide.

However, future efforts should concentrate on improving the categories and further develop them into a framework for assessing social criteria in buildings. This will serve to assist the development of more sustainable environment and help the regeneration of cities, serving as support to building practitioners, green building assessment tool and government entities to achieve sustainability in the built environment. This study is a first step towards the development of social criteria in green building assessment tool. The next step will be to 
conduct a study based on the category and indicator set derived using Delphi technique and AHP in a 2 round process with experts (academy, industry) ranging from 30-50, which would aid in the development of category and indicators set by assign weight point and sorting them in order so they can reflect the social characteristics of a building. 


\section{Reference}

Ahman, H. (2013): Social sustainability- society at the intersection of development and maintenance. Local Environment, 18(10), 1153-1166.

Ameen, R. M., Mourshed, M., and Li, H. (2015): "A critical review of environmental assessment tools for sustainable urban design," Environmental Impact Assessment Review, vol. 55, pp. 110-125.

Awadh, O. (2017): Sustainability and green building rating systems: LEED, BREEAM, GSAS and Estidama critical analysis. Journal of Building Engineering (11):25-29.

Becker, E., \& Jahn, T. (1999). Sustainability and the social sciences: Zed Books New York.

Berardi, U. (2011): Beyond sustainability assessment systems: upgrading topics by enlarging the scale of assessment, SUSB 2 (4) 276-282.

Berardi, U. (2013): Sustainability assessment of urban communities through rating systems. Environmental Development Sustainability, 15:1573-1591.

Bernardi, E., Carlucci, S., Cornaro, C., \& Bohne, R. (2017). An Analysis of the Most Adopted Rating Systems for Assessing the Environmental Impact of Buildings. Sustainability, 9(7), 1226.

Biart, M. (2002). Social sustainability as part of the social agenda of the European Community. Soziale Nachhaltigkeit: Von der Umweltpolitik zur Nachhaltigkeit, 5-10.

Bostrom, M.A, (2012): missing pillar? Challenges in theorizing and practicing social sustainability: Introductory article in the special issue. Sustainability, 8 3-14.

Boulding, K. E. (1985): The world as a total system. Sage, Beverly Hills, California, USA.

BREEAM (2016): BREEAM International New Construction 2016, Technical Manual SD233 - Issue: 1.0.BRE Global Ltd.

CASBEE (2016): CASBEE Brochure. Institute of Building Environment and Energy

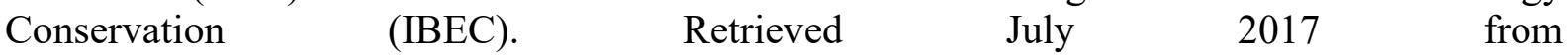
www.ibec.or.jp/CASBEE/english/document/CASBEE_brochure_2016.pdf

Casula Vifell, A. \& Soneryd, L. (2012): Organizing matters: how "the social dimension" gets lost in sustainability projects. Sustainable Development 20(1):18-27.

Chan, E. \& Lee, K. (2008): Critical factors for improving social sustainability of urban renewal projects. Social Indicators Research 85(2):243-256.

Chiu, R. L. H. (2003). Social sustainability, sustainable development and housing development: The experience of Hong Kong. In R. Forrest \& J. Lee (eds.), Housing and social change: Eastwest perspectives (pp. 221-239). USA: Routledge.

Colantonio, A. (2008). Social sustainability: a review and critique of traditional versus emerging theme and assessment method. Oxford Brookes University, UK. 
Colantonio, A. (2009); Social sustainability: a review and critique of traditional versus emerging themes and assessment methods, in: Horner, M et.al (ed); SUE-Mot Conference 2009: Second International Conference on Whole Life Urban Sustainability and its Assessment: conference proceedings, Loughborough; Loughborough University, 2009, 865.

Colantonio, A., \& Dixon, T. (2011). Urban Regeneration: Delivering Social Sustainability. Urban Regeneration \& Social Sustainability, 54-79.

Cole, R. J (2005): Building environmental assessment methods: redefining intentions, in: Proceedings of the 2005 World Sustainable Building Conference, Tokyo, pp.1934-1939.

Cole, R. J. (1999). Building environmental assessment methods: clarifying intentions. In: Building Research and Information. 27 (4/5), 230-246.

Cuthill M. (2009): Strengthening the social in sustainable development: developing a conceptual framework for social sustain-ability in a rapid urban growth region in Australia. Sustain-able Development 18(6):362-373.

Davoodi, S., Fallah, H., Aliabadi, M. (2014): Determination of affective critrions on social sustainability in architectural design. Current Trends in Technology and Science. 8th SAS Tech 2014 Symposium on Advances in Science \& Technology-Commission-IV. Iran.

Dempsey, N., Bramley, G., Powers, S., \& Brown, C. (2011): The social dimension of sustainable development: defining urban social sustainability. Sustainable Development 19(5):289-300.

Dempsey, N.; Bramley, G.; Power,S;Brown, C. (2009): The social dimension of sustainable development: Defining urban social sustainability. Sustainable Development. 19, 289-300.

DETR (2000): By design: urban design in the planning system: Towards better practice. London:Thomas Telford.

Eizenberg, E., \& Jabareen, Y. (2017). Social Sustainability: A New Conceptual Framework. Sustainability, 9(1), 68 .

Empacher, C. and Wehling, P. (1999): Indikatoren Sozialer Nachhaltigkeit. Grundlagen und Konkretisierungen, Institut fUr sozial-okologische Forschung (ISOE) (Ed.), ISOE Discussion Papers 13, Frankfurt am Main.

Endo J., Murakami S., and Ikaga T. (2007): "Application of a Building Environmental Assessment, CASBEE, and its Influence on the Building Market".

Enyedi, G. (2002). Social sustainability of large cities. Ekistics, 69 (412-414), 142-144.

Eurostat. (2007): Measuring Progress Towards a More Sustainable Europe: 2007 Monitoring Report of the EU Sustainable Development Strategy. Luxembourg: Office for Official Publications of the European Communities.

Gibberd, J. (2002): The Sustainable Building Assessment Tool, the Built Environment Professionals Conference, 1-3 May. Johannesburg. 
Green Building Council of Australia (GBCA). (2009a), "Green Star Overview, Certification". [Online]Available: http://www.gbca.org.au. Green Building Council of Australia. Sydney, Australia. 2009.

Green Building Council of Australia (GBCA). (2009c), "Green Star Eligibility Criteria. Green Building Council of Australia", Sydney, Australia. 2009. [Online] Available: http:// www.gbca.or.au. (August 6, 2012).

Green Building Council of Australia (GBCA). (2009d), "Green Star Rating Tools", Web page on the GBCA Website. Updated June 16, 2009. Green Building Council of Australia. Sydney, Australia. 2009. [Online] Available: http://www.gbca.org.au/green-star/rating-tools/ (August 6, 2012).

Griebler, E. and Littig, B. (2004): Soziale Nachhaltigkeit, Arbeiterkammer Wien (Ed.) Informationen zur Umweltpolitik 160, Wien.

GSAS (2017): Gulf Organization for Research and Development, GSAS Technical Guide 2017, Issue 2, 2017.Reteievd on July, 2017 www.gord.qa/admin/Content/Link2322017121232.pdf

Jaeger, C., Tàbara, J. D., \& Jaeger, J. (2011). European Research on Sustainable Development: Volume 1: Transformative Science Approaches for Sustainability (Vol. 1): Springer Science \& Business Media.

Komeily, A., and Srinivasan, R.S. (2015): A need for balanced approach to neighborhood sustainability assessments: a critical review and analysis. Sustainable Cities and Society, 18, 32-43.

KopfmUller, L. et al. (2001) Nachhaltige Entwicklung Integrativ Betrachtet. Konstitutive Elemente, Regeln, Indikatoren, Edition Sigma, Berlin.

LEED (2016): LEED v4 for BUILDING DESIGN AND CONSTRUCTION. United State Green Building Council: Washington, USA, p. 1-144.

LEED, (2013): LEED Reference Guide for Building Design and Construction 2013 Edition, Leadership in Energy and Environmental Design Program. US Green Building Council.

Lehtonen, M. (2004): The environmental-social interface of sustainable development: capabilities, social capital, institutions. In: Ecological Economics, Vol. 49, pp. 199-214.

Littig, B. \& Griessler, E. (2005): Social sustainability: a catchword between political pragmatism and social theory. International Journal of Sustainable Development 8(1-2):65-79.

Liu, Y., Dijst, M., Geertman, S., \& Cui, C. (2017). Social Sustainability in an Ageing Chinese Society: Towards an Integrative Conceptual Framework. Sustainability, 9(4), 658.

Loh J (ed) 2000: The Living Planet Report. WWF, Gland, Switzerland, pp1.

Lutzkendorf, T and Lorenz, D (2005) Sustainable building investment: valuing sustainable buildings through performance assessment, Building Research and Information, 33(3), pp 212 -234 . 
Mckenzie, S. (2004): Social sustainability: towards some definitions: Hawke Research Institute, University of South Australia Magil.

Murphy, K (2012): The social pillar of sustainable development: a literature review and framework for policy analysis. Sustainability: Science, Practice \& Policy, 8(1), 15-29.

New Zealand Green Building Council (NZGBC). (2009), "Green Star New Zealand Web site. New Zealand Green Building Council", 2009. Auckland, New Zealand. [Online] Available: http://www.nzgbc.org.nz/main/greenstar. (August 6, 2012).

Nguyen, B.K., \& Altan, H. (2011), "Comparative Review of Five Sustainable Rating Systems", Procedia Engineering 21, 376 - 386. 2011 International Conference on Green Buildings and sustainable cities.

Omann, I. \& Spangenberg, J. 2002. Assessing Social Sustain-ability: The Social Dimension of Sustainability in a Socio-Economic Scenario. Seventh Biennial Conference of the International Society for Ecological Economics. March 6-9, Sousse, Tunisia.

Organization for Economic Cooperation and Development (OECD). (2016): Society at a Glance 2016- OECD Social Indicators. http://www.oecd.org/social/society-at-a-glance19991290.htm. October, 102017.

Polèse, M., \& Stren, R. E. (2000). The social sustainability of cities: Diversity and the management of change: University of Toronto Press.

Sachs, I. (1999): Social sustainability and whole and whole development: exploring the dimensions of sustainable development. On: Zed Book, London.

Saunders, T. (2008): “A Discussion Document Comparing International Environmental Assessment Methods for Buildings", BRE Global. Watford, United Kingdom. March 2008.

SBTool | International Initiative for a Sustainable Built Environment. (2017). Retrieved from http://www.iisbe.org/sbmethod. (Accessed on 6th of October 2017).

Sharifi, A. and Murayama, A. (2013): A critical review of seven selected neighborhood sustainability assessment tools. Environmental Impact Assessment Review38, pp. 73-87.

Thin, N., Lockhart, C., \& Yaron, G. (2002): Conceptualizing Socially Sustainable Development. London: Department for International Development and World Bank.

United Nations Commission for Sustainable Development (UNCSD). 1996. Indicators for Sustainable Development, Framework and Methodology. http://www.un.org/esa/sustdev/natlinfo/indicators/indisd/english/english.htm. October, 10 2017.

United Nations Department of Social and Economic Affairs (UNDESA) 2001. Indicators of Sustainable Development: Framework and Methodologies. New York: United Nations.

United Nations Department of Social and Economic Affairs (UNDESA) 2007. Indicators of Sustainable Development: Guidelines and Methodologies. New York: United Nations. 
Vallance, S., Perkin, H., Dixon, J., (2011): What is a social sustainability? A clarification of concepts Geoforume, 42(3), 342- 348.

Vavik, T. \& Keitsch, M. (2010): Exploring relationships between universal design and social sustainable development: some methodological aspects to the debate on the sciences of sustainability. Sustainable Development 18(5):295-305.

Weingaertner, C., \& Moberg, Å. (2014): Exploring social sustainability: learning from perspectives on urban development and companies and products. Sustainable Development, 22(2), 122-133.

Woodcraft, S., Hackett, T. and Caistor-Arendar, L. (2011): Design for Social Sustainability: A framework for creating thriving new communities. Future Communities. 